\begin{tabular}{|l|l|l|l|}
\hline GEPHYRA & 11 & 2014 & $37-49$ \\
\hline
\end{tabular}

Hüseyin UZUNOĞLU* - Erkan TAŞDELEN**

\title{
Some New Inscriptions from the Museum of Bursa
}

\begin{abstract}
In this contribution are presented two new milestones and five grave stelai recorded during our epigraphic research in the depot and the garden of the Archaeological Museum of Bursa. It is difficult to establish where these milestones were erected, as the museum authorities are unable to provide precise information concerning their provenances. One of the milestones belongs to the reign of Diocletian-Maximian (293-305 A.D.) and gives a distance of 5 miles. The name of the Emperor Maximian was erased from the inscription following the damnatio memoriae after his death. The latter milestone dates from the reign of Philip the Arab (244-249 A.D.) and records the same distance of miles. Of the 5 funerary stones introduced, one is in Latin and one is bilingual, while the others bear Greek inscriptions. Two of the stelai (nos. 4-5) date to the Late Hellenistic while the other three (nos. 3, 6-7) date from the Roman Imperial Age and are noteworthy from the onomastic point of view as they document two new Thracian personal names corresponding to the demographic structure of the region where the stelai were found.

Keywords: Milestones; Prusa ad Olympum; funerary stelai; Greek and Latin inscriptions; onomastic; oikonomos; threptos.
\end{abstract}

Th. Corsten compiled the epigraphic material of Bursa Museum in his 'Prusa ad Olympum' corpus in 1993. A large number of new inscriptions have been brought to the museum since then and have been recorded by us within the scope of a research project funded by Akdeniz University since 2004. A new inscription corpus of the museum is in preparation, but at the same time some new inscribed material is gradually being published ${ }^{1}$. In this contribution, we introduce two new milestones and five funerary stelai preserved today in the museum.

\section{Milestones:}

The museum authorities could provide no information about the find-spot or provenance of both milestones edited below, and were unfortunately without record as to from where these stones were brought to the museum. As a result, one cannot today determine in which direction the milestones actually stood. Previously only two milestones were known from Prusa ad Olympum and from its vicinity, one of which dates from 199 A.D. (from the reign of Septimius Severus) and the other from

\footnotetext{
* Arş. Gör. Hüseyin Uzunoğlu, Akdeniz Üniversitesi, Edebiyat Fakültesi, Eskiçağ Dilleri ve Kültürleri Bölümü, Kampus TR-07058, Antalya (huseyinuzunoglu@akdeniz.edu.tr).

** Arş. Gör. Erkan Taşdelen, Akdeniz Üniversitesi, Edebiyat Fakültesi, Eskiçağ Dilleri ve Kültürleri Bölümü, Kampus TR-07058, Antalya (etasdelen@akdeniz.edu.tr).

This paper was realised within the framework of the project "The archiving of Epigraphic Materials in the Archaeological Museums of İzmit (Kocaeli), İznik and Bursa” (2009.01.0105.003), and was supported by the Akdeniz University Scientific Research Projects Coordination Unit. We are grateful to Prof. Dr. N. Eda Akyürek Şahin who suggested we publish these inscriptions, and to Enver Sağır, the former director of Bursa Archaeological Museum for his permission to work on this material.

${ }^{1}$ See for example, Akyürek Şahin 2008, 9-12; Akyürek Şahin 2010, 271-274; Akyürek Şahin - Onur 2010, 23-39; Akyürek Şahin 2014, 279-283; Uzunoğlu 2015.
} 
the reign of Gordian $\mathrm{III}^{2}$. The new milestones we publish here increase the number of milestones to four.

\section{No. 1. Milestone of Diocletian and Maximian}

The stone of cylindirical shape. The surface is slightly worn.

H: $100 \mathrm{~cm}$; Diam: $37 \mathrm{~cm}$; Lh: 2,5-4 cm.

$\mathrm{B}$ (ona) $\mathrm{F}$ (ortuna)

2 Imp(eratori) Caesar(i) C(aio) Aur(elio)Val(erio)

Diocletiano $\mathrm{p}$ (io) $\mathrm{f}$ (elici) inb(icto)

4 Aug(usto) [et ///////////////

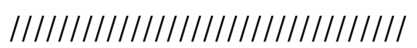

$6 \quad / / / / / / / / / / / / / / / / / / / / /$ et $\mathrm{Fl}($ avio)

\section{Val(erio) Constantio}

8 et $\mathrm{Gal}$ (erio) $\mathrm{Val}$ (erio) Maximiano

nobb(ilissimis) Caesaribus

10 a Prusae mil(ia).

vac. $\mathrm{V}$ vac.

12 vac. $\varepsilon^{\prime} \quad$ vac.

"With good fortune! To the emperor Caesar Gaius Aurelius Valerius Diocletianus pius felix invictus Augustus and to [[the emperor Caesar Marcus Aurelius Valerius Maximianus pius felix invictus Augustus]] and to the most noble Caesars Flavius Valerius Constantius and Galerius Valerius Maximianus. Five miles from Prusa.

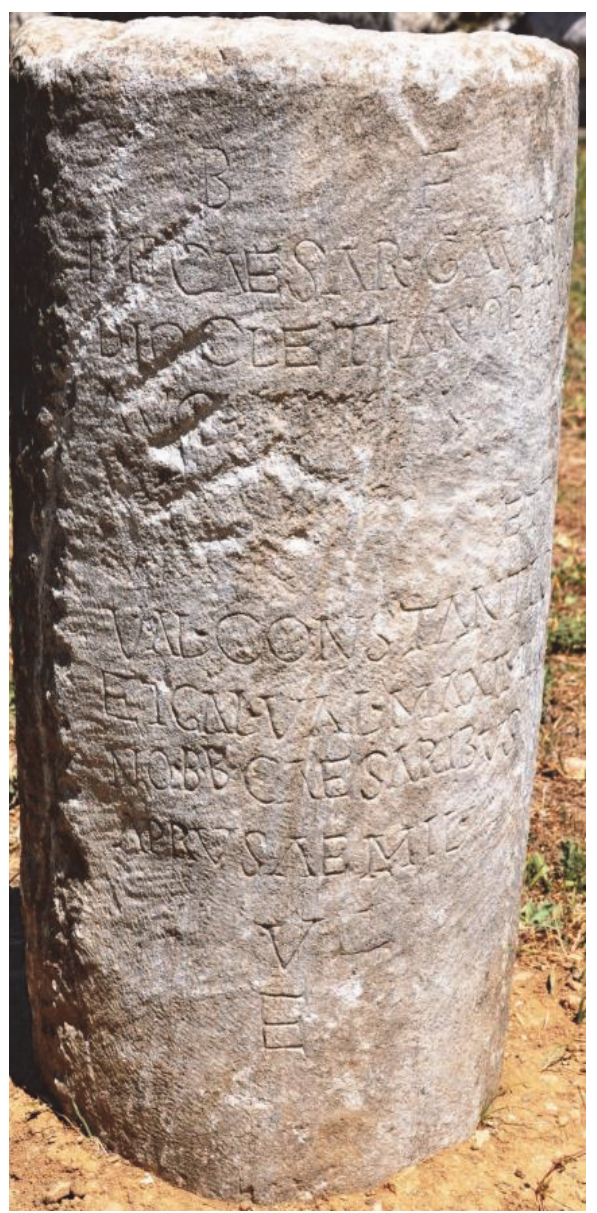

Date: $293-305$ A.D.

L. 3: inbicto = invicto. "b" instead of "v" in Latin inscriptions is prevalent, see ILS III, p. 809.

L. 6: Since the milestone dates to the Tetrarchy Period, the erased part can easily be completed in this way: [[Imp(eratori) Caesar(i) $\mathrm{M}$ (arco) Aur(elio) Val(erio) Maximiano P(io) F(elici) Inv(icto) Aug(usto)]]. Maximian, who attempted to overthrow Emperor Constantine in 311 A.D., was subjected to damnatio memoriae and his name was consequently erased from inscriptions.

L. 10-12: Five miles of distance is carved on the stone both in Latin and Greek, which is also the case for another milestone discovered in Tepecik Mevkii between Bursa and Gemlik from the period of Gordian III, see IPrusa I, 25-26, no. 11 = French 1988, no. 310 = French 2013, no. 24. The expression 'a Prusae' makes it clear that the caput viae is Prusa ad Olympum. However, the question as to in which direction this milestone was erected is a mystery as we have no information as to its find-spot unrecorded by the museum authorities nor does the inscription itself provide any indication of it. We can conjecture the milestone stood in the direction Prusa ad Olympum-Kios, as with the milestone cited above (which records the same distance of 5 miles). Yet, it is emphasized, there is no reason to exclude any other possible route, such as from Prusa ad Olympum to Apollonia ad Rhyndacum in a Western direction, to Apameia Myrleia in a North-Western direction, Hadrianoi in a Southern direction or even Dorylaion in a South-Eastern direction (see the map below in Fig. 1).

\footnotetext{
${ }^{2}$ IPrusa I, no. 10 and $11=$ French 2013, no. 2 and 24. In addition to these milestones, there is also an inscription concerning road construction during the Flavian Period in the vicinity of Prusa ad Olympum, see IPrusa I, no. 9.
} 
A Prusae: Corsten points out justifiably that this expression has a grammatical error and there was confusion among the eastern Greeks concerning the Latin cases, see in IPrusa I, 25-26, no. 11. The grammatical rule that place-names must be in the genitive case in the first and second declinations in Latin (he notices the familiar example 'Romae') was conveyed here incorrectly, since the preposition "a/ab" requires the ablative case. The correct form would have been "a Prusa" instead of "a Prusae". The person who wrote this text up most probably had in his mind that "ảmó", the ancient Greek equivalent of the Latin preposition "a/ab", was used with the genitive case, which could have caused such a mistake. For similar examples regarding this case-confusion, see INikaia II,1, no. 1008, 1. 14 (a Niceae); Şahin - Işın - Can 1983, no. 6 = French 2013, no. 63F (a Nicomediae).

No. 2. Milestone of Philip the Arab

Marble milestone. Chipped slightly at the top and left, otherwise complete. Surface partly worn. H: $125 \mathrm{~cm}$; Diam: $35 \mathrm{~cm}$; Lh: 3-6 $\mathrm{cm}$.

\begin{tabular}{|c|c|}
\hline \multirow{3}{*}{2} & $\mathrm{~B}$ (ona) $\mathrm{F}$ (ortuna) \\
\hline & Imp(erator) Caes(ar) Marcus \\
\hline & Iulius Philippus \\
\hline 4 & Pius Felix \\
\hline & Augustus \\
\hline 6 & et Marcia \\
\hline & Otacilia \\
\hline 8 & Severa \\
\hline & Augusta. \\
\hline 10 & $\varepsilon^{\prime}$ \\
\hline
\end{tabular}

"With good fortune. Imperator Caesar Marcus Iulius Philippus, pius, felix, Augustus and Marcia Otacilia Severa Augusta. 5 (milia passuum)".

Date: 244-249 A.D.

Apart from this new milestone, only two other milestones from the reign of Philip the Arab are known from the Bithynian region, see Şahin - Işın - Can 1983, no. 3 (from Libyssa) and INikaia II,1, no. 1015. The distance is again 5 miles, but we do not know from which direction this distance is given. Caput viae might well be Prusa, as is the case in no. 1 above, but there is no certainty about it.

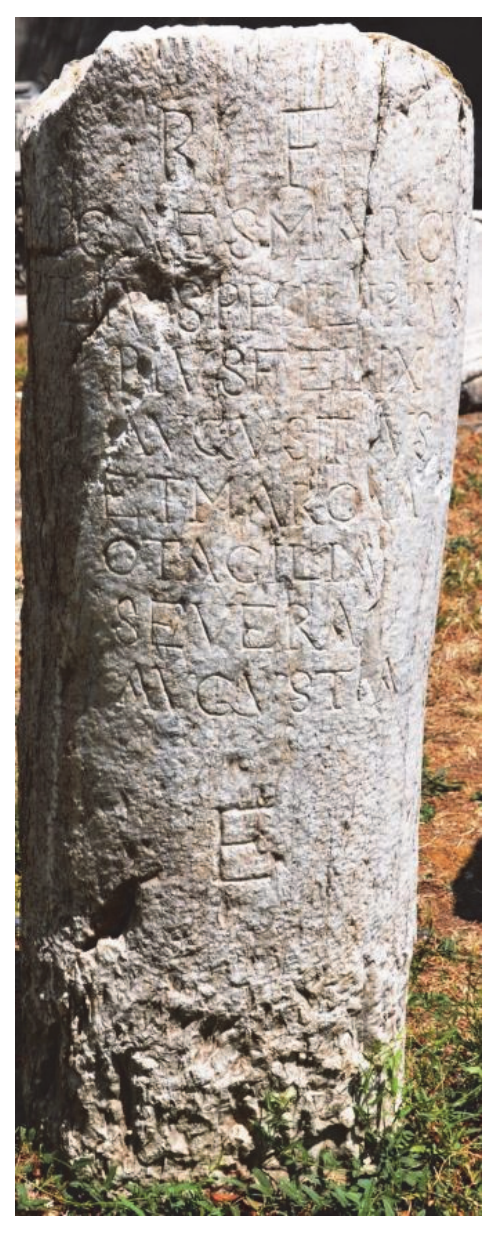

\section{Funerary Steles}

No. 3. The funerary stele of Hesperos (Fig. 2)

Large marble stele with a triangular pediment; Find-Spot: Erdoğan Köyü/Yenişehir/Bursa (purchased from a villager named Şükrü Eker in 1989); Inv. no.: 9215 (in depot); H.: $163 \mathrm{~cm}$ (with dowel); L.: 70-72 cm; D.: $11 \mathrm{~cm}$; Lh.: 2-4 cm.

The pediment has three acroteria, the top acroterium is slightly broken. A Gorgoneion is placed in the middle of the pediment. Inside the panel is depicted a typical totenmahl scene ${ }^{3}$ (funerary banquets) on the upper right. In the scene a man is depicted lying down on a kline. His left hand rests upon a

\footnotetext{
${ }^{3}$ For recent publication on the Totenmahl reliefs in Prusa ad Olympum, see Uzunoğlu 2015.
} 
cushion and he holds a wreath in his right hand in an upright position. The woman in the pudicitia pose wears a chiton with a cloak and sits on a chair, putting her feet on a rectangular foot-stool. In front of the kline is a table (mensa tripes) laden with cake and fruits. On the left of the panel is a mirror, a wool basket and a billhook (falx arboraria $a^{4}$. Beneath the totenmahl scene is seen a boy (a servant?) holding the reins of a horse. A Greek inscription of six lines is carved beneath the relief field. The stele has a small and partly broken dowel.

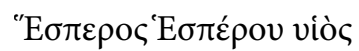

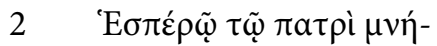

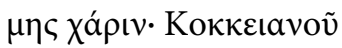

$4 \Lambda \operatorname{I\Pi NO\Sigma } \theta \rho \varepsilon \dot{\pi} \tau \omega$ oỉкo-

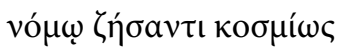

6 हैंๆ $\pi \varepsilon v \tau \eta \dot{\kappa o v \tau \alpha . ~}$

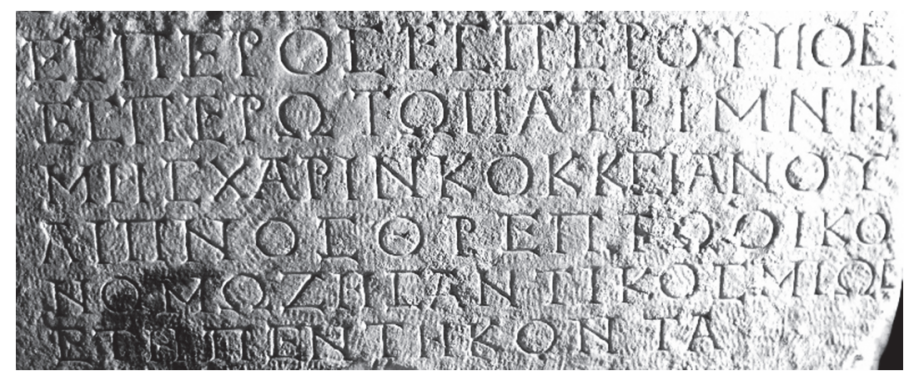

"Hesperos, son of Hesperos, (erected the stele) for his father Hesperos in memory of him, who was the threptos and oikonomos (administrator) of Cocceianus ....... (and) lived fifty years decently".

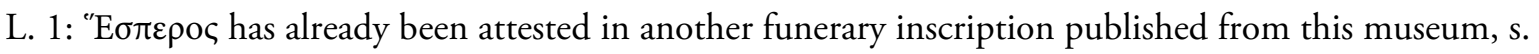
IPrusa I, no. 165. He is likewise an oikonomos (of Tiberius Claudius Polion Phaedrus) and has a son who carries the same name of Hesperos as is the case in our inscription. The name is also recorded in Nikomedeia in Bithynia, TAM IV 1, no. 279; For other attestations in the other regions, see LGPN V

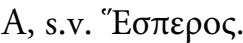

L. 2: Коккєıаvóc: The cognomen Cocceianus was carried by two famous citizens of Prusa (the orator Dio Chrysostom and the historian Cassius Dio). For a further epigraphic evidence, see IPrusa I, no. 99.

L. 4: $\Lambda \mathrm{I} \Pi N O \Sigma$ : This word is puzzling and the meaning is not easy to comprehend, as to our knowledge, such a word does not exist in ancient Greek. It might well be a personal name which has not to date been documented. In this case, it would be even stranger and harder to identify this Lipnos or Aipnos, given the clear statement in the upper lines that Hesperos is the one who erected the stele. It seems us more reasonable to comment upon it as the genitive form of the father's name of Cocceianus whose nominative form can not be established.

$\theta \rho \varepsilon ́ \pi \tau o c:$ There are four attestations of the threptoi in the inscription catalogue of Prusa ad Olympum, see IPrusa I, no. 74; 101; 121; 156. On their legal and social status in general, see the excellent study made by M. Ricl (2009, 93-117). For the Lydian and Phrygian cases specifically, see also Ricl 2005, 145-166 and Ricl 2006, 293-321. In the inscription, it is pointed out that Hesperos was charged with the management of the land, after being raised by Cocceianus. We can not determine the status of Hesperos from the term $\theta \rho \varepsilon ́ \pi \tau o \varsigma$ itself, since "the term was used to convey different meanings and designate both slave and free individuals", see Ricl 2009, 97. However, that the Hesperos in question is also mentioned as oikonomos in the inscription is secure evidence that he was unfree or rather a freedman.

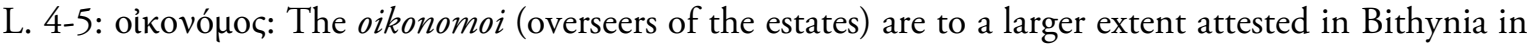
Asia Minor. For the examples see TAM IV.1, nos. 57 and 150; INikaia I, nos. 192, 196, 205; INikaia II,1, nos. 753, 1057, 1062, 1201; INikaia II.2, nos. 1292, 1336, 1413, 1466; IKalchedon, no. 101; IPrusias, no. 103; IKios, nos. 46 and 91; Adak - Akyürek Şahin 2005, nos. 5 and 6; Çokbankir 2010,

\footnotetext{
${ }^{4}$ For falx arboraria, see White 1967, 85-88. This implement is commonly depicted on the grave stelai of Prusa ad Olympum and from its vicinity; see for example Akyürek Şahin 2010, no. 3-6 and Uzunoğlu 2015, 405-408, nos. 3-6. Cf. also Corsten 1990, 92. For the agricultural implements on the grave stelai in general, cf. also Pfuhl - Möbius 1979, 542 .
} 
330-331, nos. 1 and 12; 336-337, no. 12; Öztürk - Aslan 2012, 104-105, no. 7, cf. Marek 2003, 75. Aside from this new one, there are three other oikonomos documents from Prusa ad Olympum, see IPrusa I, nos. 68 and 165; Uzunoğlu 2015, 402-403, no.1. As the abundance of the examples demonstrates, one can easily deduce Bithynia was relatively rich in terms of estates. S. Şahin explains this phenomenon as due to the fact that the region enjoyed a mild climate and possessed significant water resources, see INikaia II.1, no. 1062, p. 188b. On the oikonomos in detail, see Landvogt 1908; Ziebarth 1937, 2118-2119; INikaia II.1, p. 187-188; Marek 1993, 114; Marek 2003, 114; Fernoux 2004, 238252; Corsten 2006, 87, fn. 11; cf. Öztürk - Sönmez 2011, 160-161; Marek 2010, 555 and 574.

Date: From the style of lettering employed $2^{\text {nd }}$ century A.D.

No. 4. The funerary stele of Teres and his children (Fig. 3)

Marble stele. Upper part broken, otherwise complete; Find-Spot: İsmetiye Köyü/Büyükorhan/Bursa; Inv. no.: 9634 (in depot); H.: $106 \mathrm{~cm}$ (with dowel); L.: 51-54 cm; D.: 9-11 cm; Lh.: $2 \mathrm{~cm}$.

The stele has at least two figural relief panels (Stockwerkstele). The scene in the upper panel is fragmentary, but it is almost certain that a funerary banquet was depicted (cf. above no. 3). On the left is depicted a table. The bottom part of the woman's chiton is seen near it and the woman has her feet upon a foot-stall. In the middle is placed a mensa tripes laden with fruit and cakes. On the right side is depicted a person (most probably a servant). There is a fighting scene in the lower panel. The fighter on the left has a round shield, holds a long sword (?) and wears a helmet and short chiton. His rival on the right is equipped with a long spear and a gallic shield streching from his head down to his feet 5 . Beneath the fight scene is carved a Greek inscription in four lines.

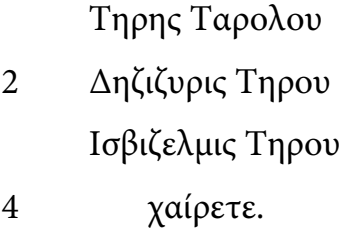

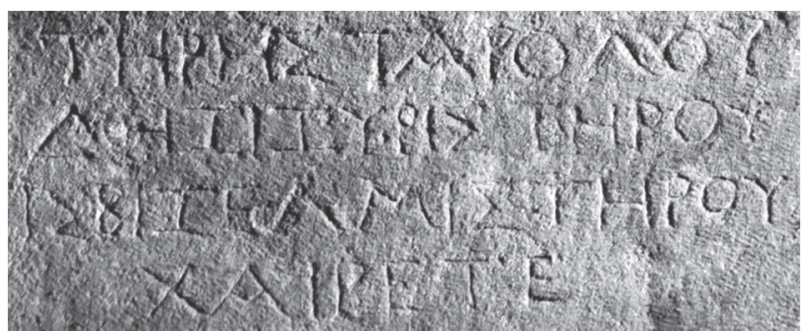

"Teres, son of Taroulas; Dezizyris, son of Teres; Isbizelmis, son of Teres; Farewell!"

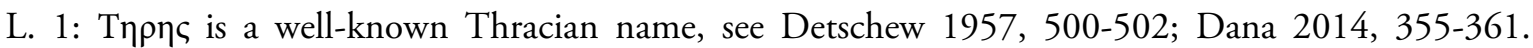

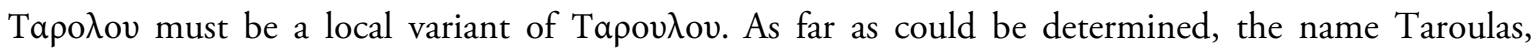
clearly also a Thracian name, is here recorded in Asia Minor for the first time, excluding another possible variant "Ta入oupac" carved on an amphora stamp in Pergamon, see IPergamon II, no. 1296. For the name in general see Detschew 1957, $491-492$ and Dana 2014, 349-350. For the names starting with -Tarou stem, cf. Detschew 1957, 490.

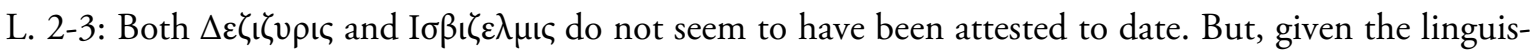
tic features (the endings -zuris and -zelmis) and the density of the Thracian population within the Bithynian region, it is obvious that these are Thracian personal names ${ }^{6}$. For the Thracian names ending with -zelmis, see Detschew 1957, 181 and Dana 2014, 389 and the names ending with -zuris, see

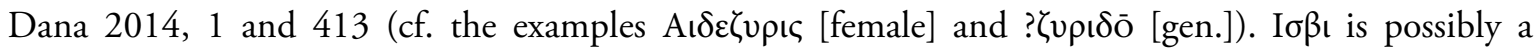
variant of Esb/Ezb-, cf. Dana 2014, 184-185. The inscription gives us no clue concerning the gender

\footnotetext{
${ }^{5}$ For another stele with a very similar fight scene in the museum of Bursa (excluding the lowering position of the spear of the fighter on the right and the dead person between them), see Pfuhl - Möbius 1979, 309, no. 1273. Pfuhl Möbius (loc.cit.) date the stele to the $2^{\text {nd }}$ century B.C. and wonder if this stele should remind us of the Gallic Wars in Asia Minor.

${ }^{6}$ We owe a debt of gratitude to Dr. Dan Dana for sharing his opinion concerning these new names and also providing us with his recently published contribution to Thracian onomastic.
} 
of these persons. However, based upon the substantial number of examples indicating that $-\zeta \varepsilon \lambda \mu \iota \varsigma$ is a

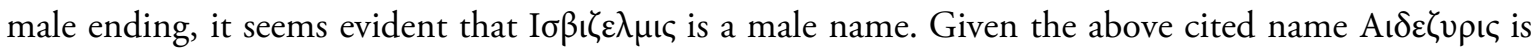

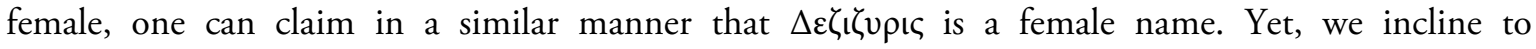
understand it as a male name. On Thracian names in Bithynia and the onomastics of the indigenous people of north-western Asia Minor in general see Özlem-Aytaçlar 2010, 506-529 = Özlem-Aytaçlar 2012, 63-113 (in Turkish).

Date: Presumably Late Hellenistic from the lettering style employed.

No. 5. The funerary Stele for Meidias (Fig. 4)

Large marble stele with a triangular pediment; Find-Spot: Unknown. Now in the garden of the museum. Inv. no.: 2002-132; H.: $150 \mathrm{~cm}$ (with dowel); L.: $45-50 \mathrm{~cm}$; D.: 10-13 cm; Lh.: 1-1,5 cm.

The relief field of the stele is broken and only lower part of the depiction remains visible today. A rider wearing a chiton in the lower panel of the stele gallops his horse to the right. On his left side is depicted a servant with a short spear ${ }^{7}$. Beneath the relief is carved a Greek inscription in five lines.

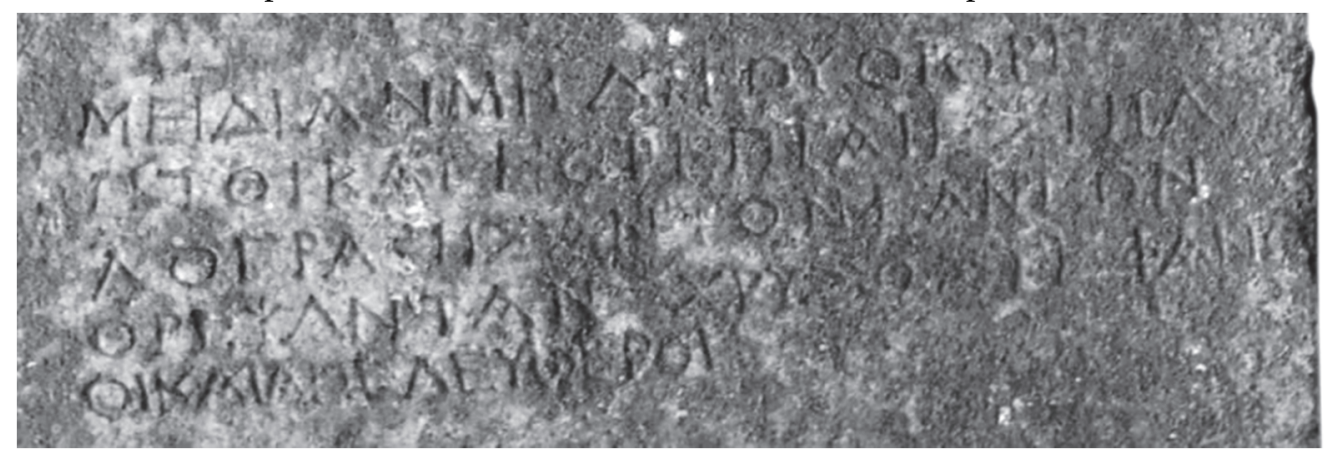

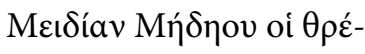

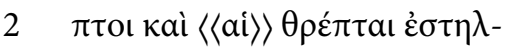

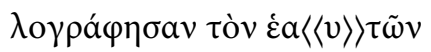

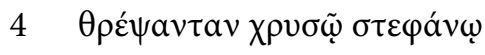

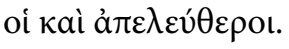

"Threptoi and Threptai and (also his) freedmen honoured their nurturer Meidias, son of Mede(i)os with a golden wreath."

L. 1: The personal name Meı́ías is notably popular in Mysia, see LGPN V A, p. 287. We have only four attestations from Bithynia, all from the corpus of Prusa ad Olympum, see IPrusa I, nos. 46, 48 b,

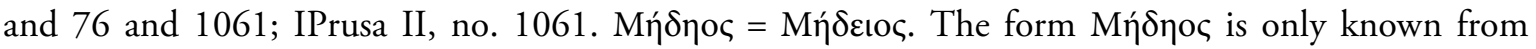
Nikaia, see INikaia, 1381.

L. 2: $\dot{\eta}$ instead of $\alpha \dot{i}$, on the stone.

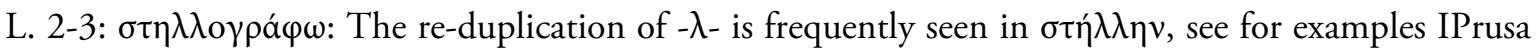
I, nos. 105 and 160; see also Brixhe 1984, 32. This seems to be the second documentation of this reduplication when it compounds with the verb " $\gamma \rho \alpha \dot{\varphi} \varphi \omega$ ". The verb, which is normally translated as "to engrave on a stele" and was mostly employed in the confession inscriptions [cf. SEG 33, no. 1013; SEG 42, no. 1082; MAMA IV, nos. 282 and 286 etc.], is apparently employed here in the sense of

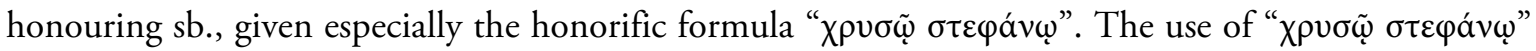
in a funerary context is also known from Paros, see IG XII/5, 314. Cf. McLean 2002, 261-263. It

\footnotetext{
${ }^{7}$ For similar scenes from the vicinity of Bursa with a rider on his horse and a standing servant, see for instance Pfuhl Möbius 1979, no. 687 and Cremer 1992, 124, no. NS4.
} 
seems worthwhile to mention here that several unpublished funerary stelai preserved today in the museum of Bursa and recorded by our team members bear the names of the deceased in the accusative

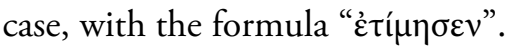

L. 3: EANT $\Omega N$ on the stone.

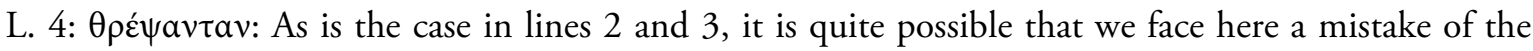
stonemason, who carved the letter " $v$ " needlesly. If this was the case, it would then be the aorist active

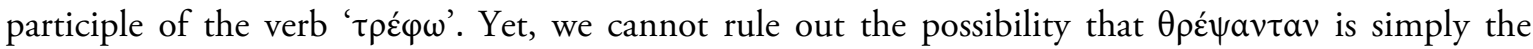
accusative form of a substantive " $\theta \rho \varepsilon ́ \psi \alpha \nu \tau \alpha \varsigma$ ", which does not have an entry in the dictionary of Liddle - Scott. The form has been attested twice to date, both from the region of Lydia, see TAM V,1 nos. 752 and 753.

L. 5: oi kaì à $\varepsilon \varepsilon \lambda \varepsilon v ́ \theta \varepsilon \rho o$ must have been inserted at a later date, because it stands as a subject at the end

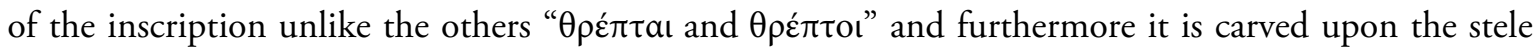
in a narrower style.

Date: late Hellenistic (from the lettering style employed)

No. 6. The Funerary Stele of Vaicia and Iucundus (Fig. 5)

Marble stele. Provenance: Unknown. Inv. no.: 9638. H.: 51 cm; L.: 37,5 cm; D.: 9 cm; Lh.: $2 \mathrm{~cm}$.

The relief field of the stele is almost completely broken and it is not possible to determine the theme of this relief. Only the lower piece of a relief carving of a garment survives. The right side of the shaft is also damaged and broken into two pieces. A four line inscription is carved beneath the relief.
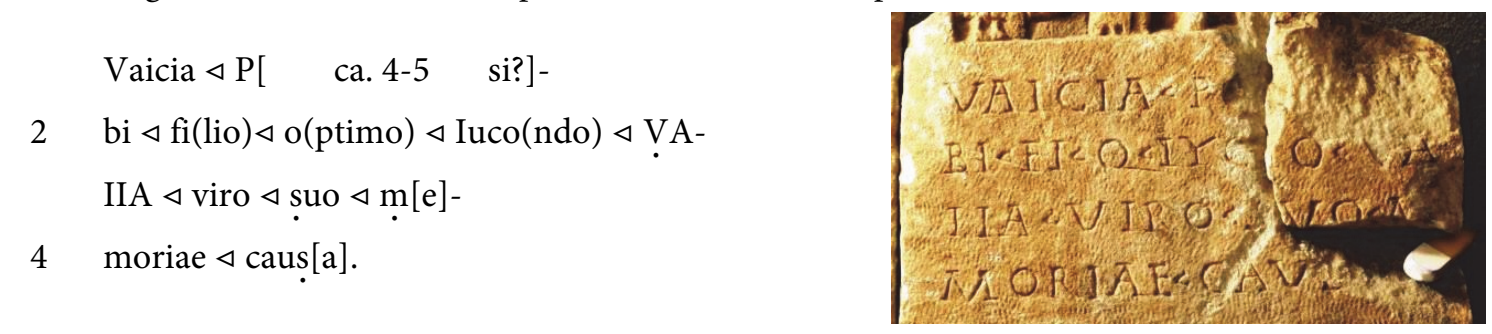

"Vaicia P... (erected the stele) for herself, for her very good son Iucundus (and) her husband Vaiia? out of respect for their memory".

L. 1: Vaicia is clear to read on the stone, notwithstanding the fact that there is no attestation of this name in any source as far as we could determine. P may refer to the father name of Vaicia, if not her second name.

L. 2: Iucondo = Iucundo. For "o" instead of "u", cf. ILS III, p. 828. "V" is carved as an Ypsilon by the Greek stonemason, cf. IPrusa I, no. 172. The space between $\mathrm{C}$ and $\mathrm{O}$ seems a bit longer and the break seperates them. So, Iuc(undo) is also possible here, but $\mathrm{O}$ would require to be clarified in this case, which could be a part of the name of Vaicia's husband. For the cognomen Iucundus, cf. Kajanto 1965, 72-73.

L. 2-3: VAIIA is not easy to understand. If we assume that Vaiia, a name unattested to date, is indeed the name of Vaicia's husband, it would mean that the stonemason forgot the letter "E" (VAIIAE), maybe he thought in the ancient Greek way, in which case the iota was often left out in dative cases. For such a case confusion, cf. above no. 1.

Date: Roman Imperial Period

No. 7. The Funerary Stele of Titus Anicius Eros (Fig. 6).

Marble stele with triangular pediment. Find-Spot: Gemlik/Bursa; Inv. Nr: 2013/62. H.: 78 cm; L.: 40 cm; D.: 7 cm; Lh.: 2,5.

The stele has one top and two corner acroteria. The left acroterion is completely broken. The recessed 
figural relief panel contains four standing figures, a man, a woman and two children. The man with short, curly hair, stands frontally and holds his right arm to his chest, grasping the folds of his cloak. The woman also stands frontally and is depicted with her right hand on her shoulder. In the corners of the panel are the small figures of a boy on the left and a girl on the right. The boy's arms are held in front of him, his right hand holding his left wrist. The little girl stands erect and faces the viewer. She wears a long dress and holds her arms in front of her, her right hand grasping her left wrist. Beneath the relief is a bilingual inscription of five lines carelessly carved.

Titus Anicius, T(iti) l(iberti) Eros

$2 \quad \operatorname{Sal}(\mathrm{ve})$

Títos 'Avíkıৎ

4 Títov ảं $\varepsilon \lambda \varepsilon v \dot{\theta} \theta \varepsilon \rho \varsigma$

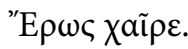

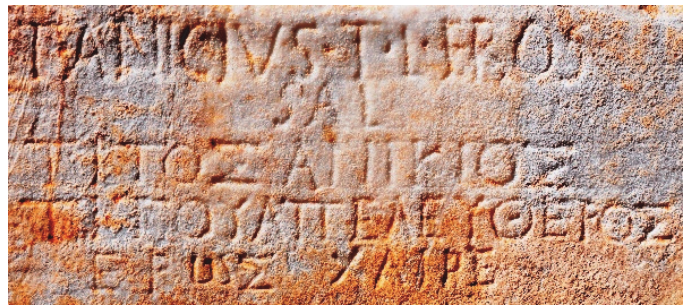

“Titus Anicius Eros, freedman of Titus. Farewell!

Date : Presumably $2^{\text {nd }}$ century A.D. from the style of lettering employed.

\section{Abbreviated Literature}

Adak - Akyürek Şahin 2005

Akyürek Şahin - Onur 2010

Akyürek Şahin 2008

Akyürek Şahin 2010

Akyürek Şahin 2014

Brixhe 1984

Corsten 1990

Corsten 2006

Cremer 1992

Çokbankir 2010

Dana 2014

Detschew 1957

Fernoux 2004

French 1988
M. Adak - N. E. Akyürek Şahin, Katalog der Inschriften im Museum von Adapazarı, Gephyra 2, 2005, 133-172.

N. E. Akyürek Şahin - F. Onur, Neue Grabinschriften im Museum von Bursa, Gephyra 7, 2010, 23-39.

N. E. Akyürek Şahin, Ein Epigramm aus Nikaia: Klage einer Mutter über den frühen Tod ihrer Kinder, in: E. Winter (ed.), Vom Euphrat bis zum Bosporus. Kleinasien in der Antike. Festschrift für Elmar Schwertheim zum 65. Geburtstag (Asia Minor Studien 65), Bonn 2008, 10-12.

N. E. Akyürek Şahin, Zwei neue Inschriften für Hosios kai Dikaos, Olba 18, 2010, 267-280.

N. E. Akyürek Şahin, Bursa Müzesi'nde Klasik Dönem’e Ait Bir Epigram, in: Ç. Akşit et al. (ed.), In memoriam Filiz Öktem, Ankara 2014, 279-283.

Cl. Brixhe, Essai sur le grec anatolien au début de notre ère, Nancy 1984.

Th. Corsten, Neue Grabstelen mit Totenmahlreliefs aus der Gegend von Prusa ad Olympum, EA 16, 1990, 91-108.

Th. Corsten, The Role and Status of the Indigenous Population in Bithynia, in: T. Bekker-Nielsen (ed.), Rome and the Black Sea Region. Domination, Romanisation, Resistance, Aarhus 2006, 85-93.

M. Cremer, Hellenistisch-römische Grabstelen im nordwestlichen Kleinasien 2. Bithynien (Asia Minor Studien 4.2), Bonn 1992.

N. Çokbankir, Modrena ve Nikaia Teritoryumundan Yeni Yazıtlar, Olba 18, 2010, 323-345.

D. Dana, Onomasticon Thracicum (OnomThrac). Répertoire des noms indigènes de Thrace, Macédoine Orientale, Mésies, Dacie et Bithynie, Athens, Athens 2014 (MELETHMATA 70).

D. Detschew, Die Thrakische Sprachreste, Vienna 1957 (Schriften der Balkankommission XIV).

H. L. Fernoux, Notables et élites des cités de Bithynia aux époques hellénistique et romaine (IIIe siècle av. J.-C.-III e siècle ap. J. C.), Lyon 2004.

D. H. French, Roman Roads and Milestones of Asia Minor. Fasc. 2.1: An 
French 2013

Kajanto 1965

Landvogt 1908

Marek 1993

Marek 2003

Marek 2010

McLean 2002

Özlem-Aytaçlar 2010

Özlem-Aytaçlar 2012

Öztürk - Aslan 2012

Öztürk - Sönmez 2011

Pfuhl - Möbius 1979

Ricl 2005

Ricl 2006

Ricl 2009

Şahin - Işın - Can 1983

Uzunoğlu 2015

White 1967

Ziebarth 1937
Interim Catalogue of Milestones (British Institute of Archaeology at Ankara Monograph no. 9), Oxford 1988.

D. H. French, Roman Roads and Milestones of Asia Minor. Vol. 3 Milestones, Fasc. 3.4 Pontus et Bithynia (British Institute at Ankara, Electronic Monographs 4), Ankara 2013.

I. Kajanto, The Latin Cognomina, Helsinki 1965.

P. Landvogt, Epigraphische Untersuchungen über den Oikonomos. Ein Beitrag zum hellenistischen Beamtenwesen, Strasbourg 1908.

Chr. Marek, Stadt, Ära und Territorium in Pontus-Bithynia und Nord Galatia, Tübingen 1993.

Chr. Marek, Pontus et Bithynia. Die römischen Provinzen im Norden Kleinasien, Mainz am Rhein 2003.

Chr. Marek, Geschichte Kleinasiens in der Antike, Münich 2010.

B. H. McLean, An Introduction to Greek Epigraphy of the Hellenistic and Roman Periods: From Alexander the Great to the Reign of Constantine (323 B.C. - A.D. 337), Ann Arbor 2002.

P. Özlem-Aytaçlar, An Onomastic Survey of the Indigenous Population of North-western Asia Minor, in: R. W. V. Catling - F. Marchand (edd.), Onomatologos. Studies in Greek Personal names presented to Elaine Matthews, Oxford 2010, 506-529.

P. Özlem-Aytaçlar, Kuzeybatı Küçük Asya'nın Yerel Halklarının Onomastiği Üzerine Bir Araştırma, şurada: N. E. Akyürek Şahin - B. Takmer - F. Onur (edd.), Eskiçağ Yazıları 1, Antalya 2012, 63-113 (Akron. Eskiçă̆ Araştırmaları 1).

H. S. Öztürk - S. K. Aslan, Nikaia'dan Yeni Yazıtlar II, Gephyra 9, 2012, 101-110.

B. Öztürk - İ. F. Sönmez, New Inscriptions from Karadeniz Ereğli Museum

II, Arkeoloji ve Sanat Dergisi 137, 2011, 155-166.

E. Pfuhl - H. Möbius, Die ostgriechischen Grabreliefs II, Mainz 1979.

M. Ricl, Legal and Social Status of $\theta \rho \varepsilon \pi \tau o$ and Related Categories in the

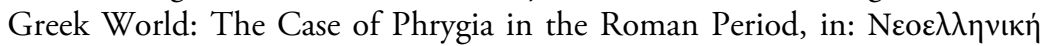

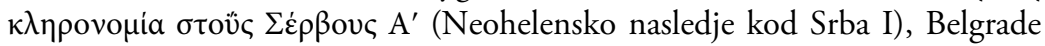
2005, 145-166.

M. Ricl, Legal and Social Status of $\theta \rho \varepsilon \pi \tau$ oi and Related Categories in the Greek World: The Case of Lydia in the Roman Period, in: Recueil de travaux de la Faculté de philosophie série A: Les sciences historiques vol. XX: Sobria Ebrietas: Mélanges offerts à Miron Flaŝar, Belgrade 2006, 293-321.

M. Ricl, Legal and social status of threptoi and related categories in narrative and documentary sources, in: H. Cotton - R. Hoyland - D. Wasserstein (edd.), From Hellenism to Islam: Cultural and Linguistic Change in the Roman Near East, Cambridge 2009, 93-114.

S. Şahin - M. A. Işın - M. K. Can, Acht Meilensteine aus Libyssa, Epigraphica Anatolica 1, 1983, 41-55.

H. Uzunoğlu, Bursa Müzesi'nden Ölü Ziyafeti Sahneli Yeni Mezar Stelleri, Olba 23, 2015, 397-415.

K. D. White, Agricultural Implements of the Roman World, Cambridge 1967.

E. Ziebarth, Oikonomos, in: RE 17.2, 1937, col. 2118-2119. 


\section{Özet}

\section{Bursa Müzesi’nden Bazı Yeni Yazıtlar}

Bu makalede Bursa Arkeoloji Müzesi'nin depo ve bahçesinde kaydedilen 2 adet yeni mil taşı ile 5 adet yeni mezar steli ele alınmaktadır. Müze yetkililerin verdiği bilgilerden, miltaşlarının Bursa çevresinden geldiği hemen hemen kesindir. Buna rağmen kesin buluntu yerlerinin bilinmiyor oluşu bu taşların hangi antik güzergah üzerinde konulmuş olduğunu belirlememizi imkansızlaştırmaktadır. İlk miltaşı Diocletianus-Maksimianus (İ. S. 293-305) dönemine aittir ve caput viae olarak gösterilen Prusa ad Olympum kentinden itibaren 5 millik bir mesafe vermektedir. İmparator Maksimianus'un adı, Constantinus tarafından damnatio memoriae ya uğramasının sonucu olarak yazıt üzerinden kazınmıştır. Diğer mil taşı ise İmparator Philippus (İ. S. 244-249) devrindendir ve mesafe, diğer yazıta benzer şekilde 5 mil olarak gösterilmiştir. Makalede tanıtılan mezar taşlarından birisi Latince, bir diğeri Latince ve Yunanca çift dilli, diğerleri ise Yunancadır. İkisi (no. 4 ve 5 ) olasılıkla Geç Hellenistik Dönem'den, diğerleri ise Roma İmparatorluk Çağı'ndan olan mezar stelleri onomastik açıdan dikkate değer olup ayrıca iki adet yeni Thrak ismini de belgelemektedir. Yazıtların çevirileri ise şöyledir:

1. "Hayırl uğurlu olsun! Dindar, bahtiyar (ve) yenilmez Augustus Imparator Caesar Gaius Aurelius Valerius Diocletianus ve [[Dindar, bahtiyar (ve) yenilmez Augustus Imparator Caesar Marcus Aurelius Valerius Maximianus]] ve pek asil Caesar'lar Flavius Valerius Constantius ve Galerius Valerius Maximianus'a! Prusa'dan 5 mil(ia passuum)."

2. "Hayırl uğurlu olsun! İmparator Caesar Marcus Iulius Philippus, dindar, bahtiyar Augustus ve Marcia Otacilia Severa Augusta. 5 (milia passuum)".

3. "Hesperos oğlu Hesperos ... oğlu? Cocceianus'un beslemesi ve kahyası olan ve 50 sene düzgün bir şekilde yaşayan babasının anısına (bu steli diktirdi)".

4. "Taroulas oğlu Teres, Teres oğlu Dezizyris, Teres oğlu Isbizelmis. Elveda!"

5. "Erkek ve kadın beslemeleri ve azatlllar, hamileri Medeios oğlu Meidias'ı altın bir çelenk ile onurlandırdılar."

6. "Vaicia, kendisi, biricik oğlu Iucundus ve kocası Vaiia? için anıları vesilesiyle (bu steli diktirdi)".

7. "Titus'un azatllsi, Titus Anicius Eros. Elveda!".

Anahtar Sözcükler: Miltaşı; Prusa ad Olympum; mezar stelleri; Yunanca ve Latince yazıtlar; onomastik; oikonomos; threptos. 


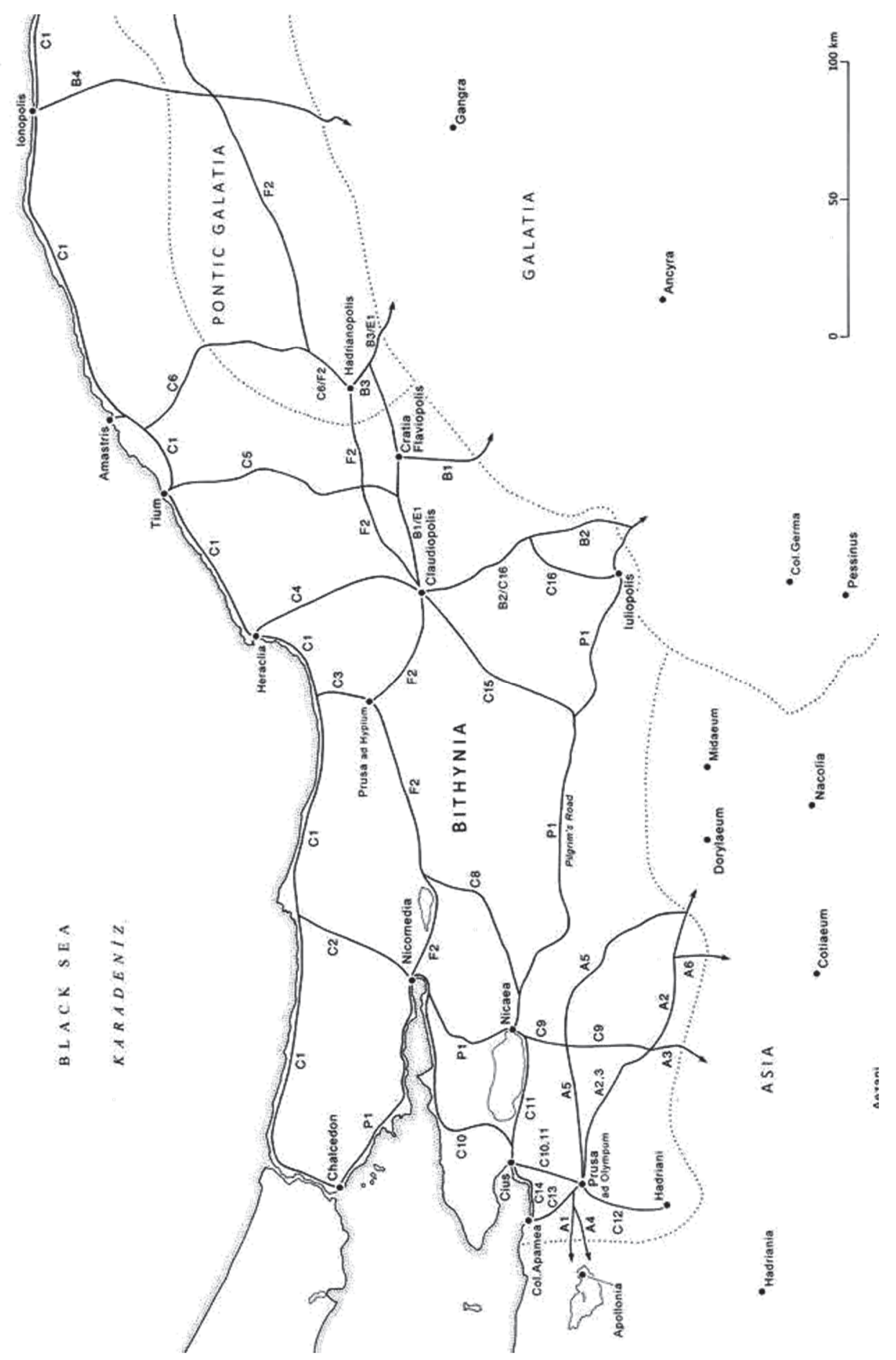

Fig. 1) The road network of Bithynia and its vicinity (after French 2013, 20, Map no. 5.1.1) 

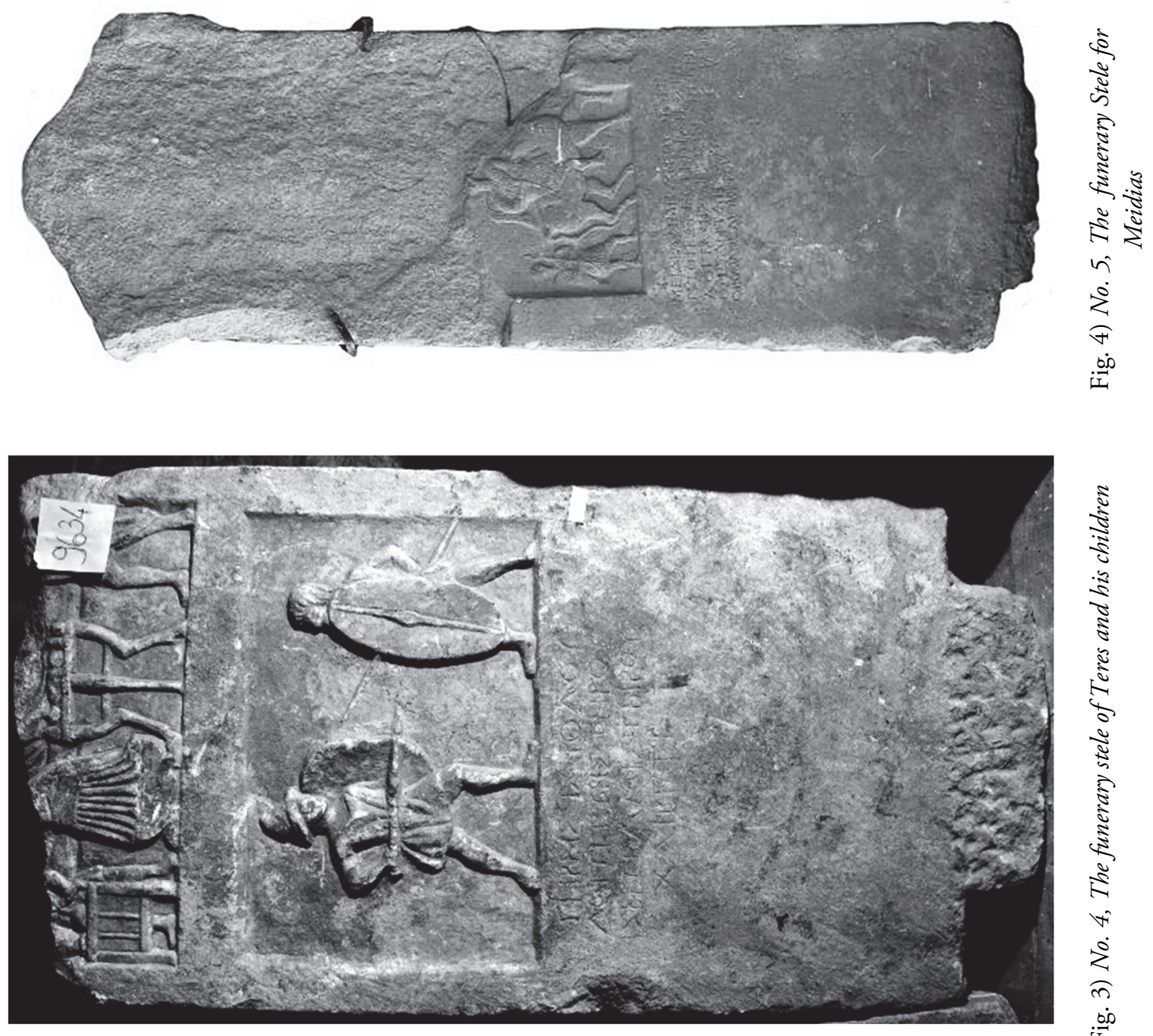

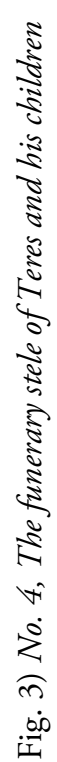

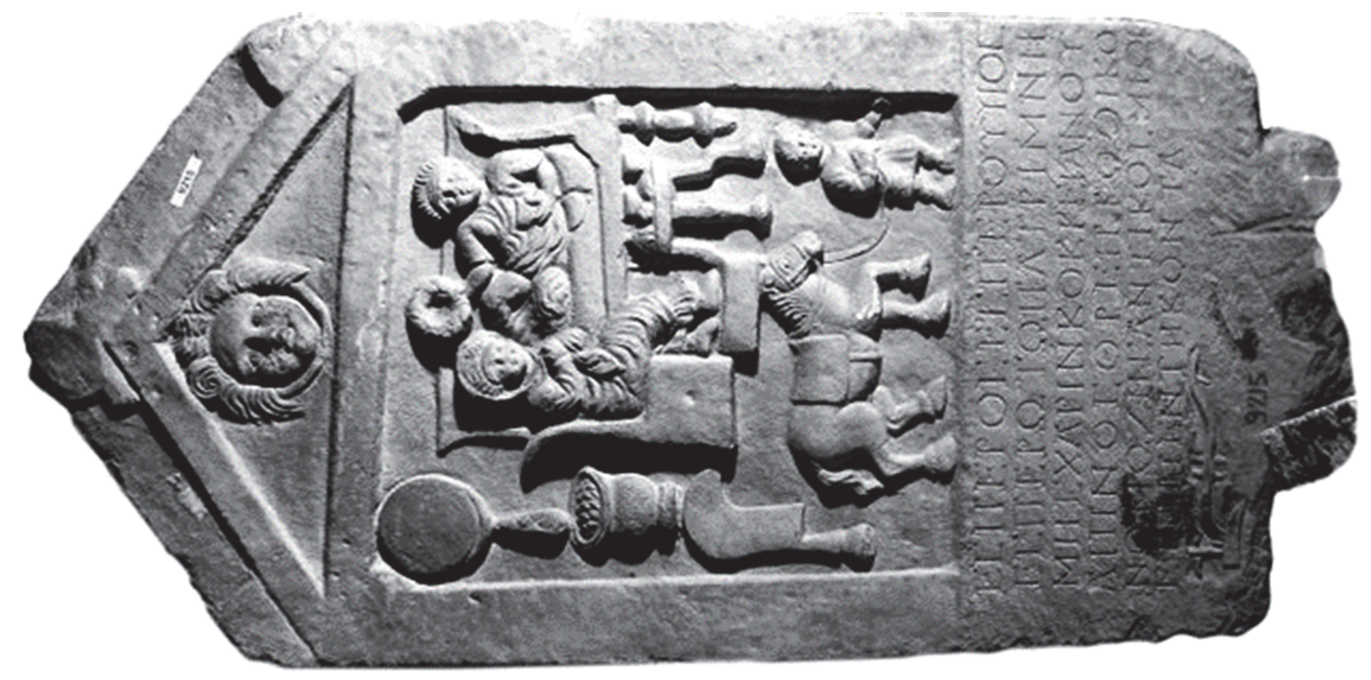

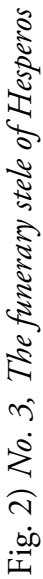



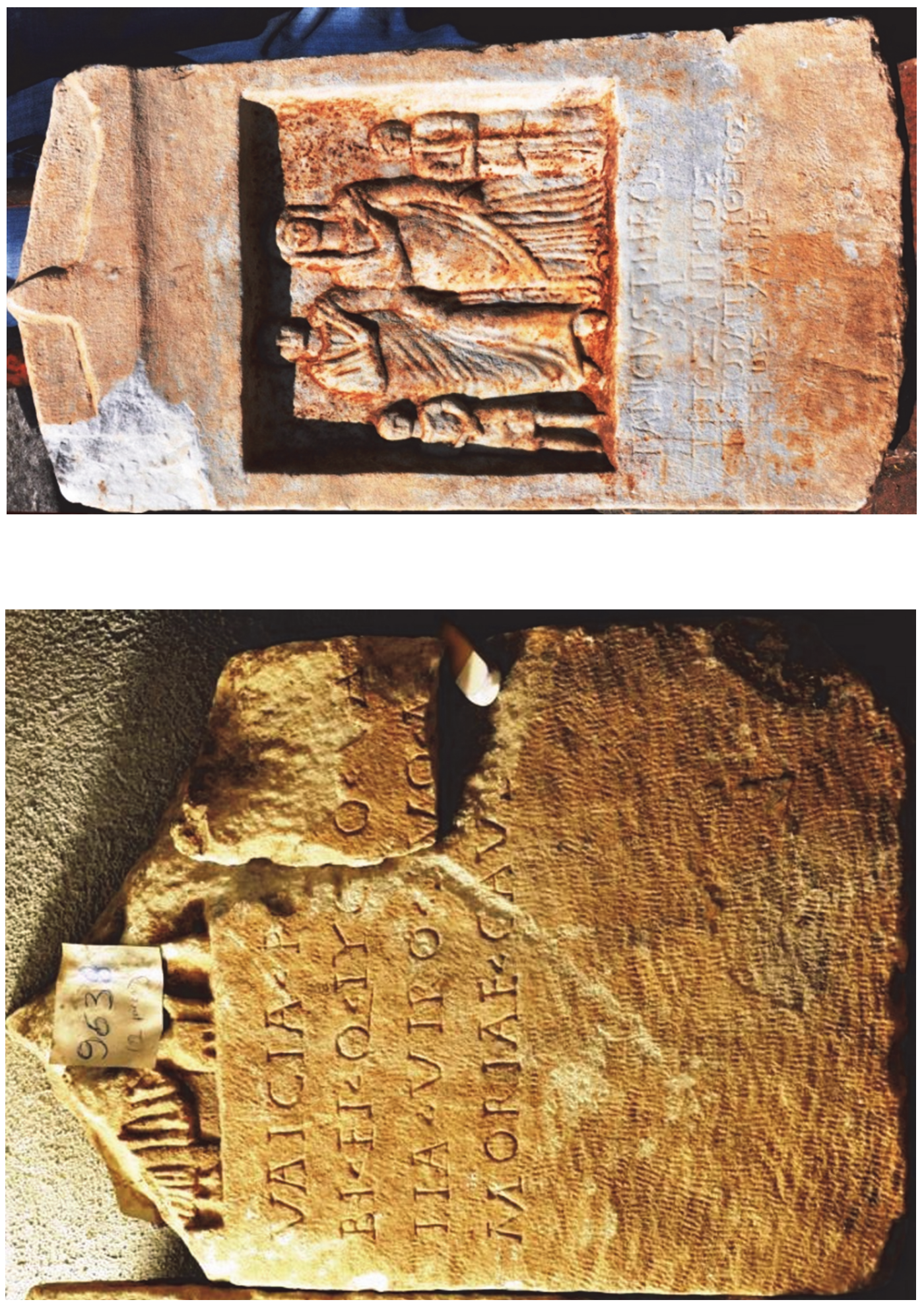